\title{
Silica-Cemented Terrace Edges, Central California Coast
}

\author{
L. E. Moody* and R. C. Graham
}

\begin{abstract}
The morphologic development of soils on marine terraces is a function of terrace age and geomorphic evolution. In this study, interrelationships between terrace landscape evolution and pedogenic silica cementation were investigated. Soil morphology, micromorphology, selective dissolution, penetration resistance, and hydraulic conductivity were used to determine the nature and extent of the cementation and evaluate the effect of cementation on soil properties. Soils on the interior part of the terrace (coarse-loamy, mixed, thermic Typic Epiaquolls) contain plinthite, continuous throughout the entire terrace, cemented to the extent that it is only slowly permeable. A seasonally perched water table develops above the plinthite, and water seeps out of soils at the terrace edges. Some of these soils are cemented by opaline silica, in both channels and interstitial voids. The silica cementation extends inward into the terrace soils only $4 \mathrm{~m}$, but at the terrace edge is strong enough to result in block fall as the predominant mechanism of scarp retreat. Redoximorphic Fe depletions are prominent in deeper horizons at the edge, but are absent from the interior. These depletions are formed through seasonal saturation and Fe reduction, by water seeping laterally through preferential flow paths in and adjacent to shrinkage cracks above the regolith-bedrock contact. Contrasting morphology and chemistry between terrace interior and edge both result from, and cause, the interaction of pedogenic processes and landscape evolution. Contrasts between interior and edge soils suggest that caution is essential in using edge exposures as representative of soils under a geomorphic surface.
\end{abstract}

$\mathrm{I}^{\mathrm{N}}$ ARID AND SEMIARID climates, silica cementation in some soils results in hard aggregates (durinodes) or horizons (duripans) that do not slake in water. In arid regions, silica cementation in soils is generally accompanied by calcite (Chadwick et al., 1987; Boettinger and Southard, 1990), whereas in semiarid climates, silica cementation is often associated with Fe oxides (Torrent et al., 1980). Duripans are found in very old soils on intrusive igneous rocks and the sediments derived from them, or in young soils that contain rapidly weathering, siliceous volcanic ash (Flach et al., 1969) or siliceous loess (Blank and Fosberg, 1991). Silcretes are similar to duripans in that they are cemented with silica as a result of low-temperature, surface or near-surface processes, but silcretes also include silica-cemented geologic material, as well as soils (Bates and Jackson, 1984; Ollier, 1991), and are not associated with either calcite or Fe oxides (Ollier, 1991). Once formed, both silcretes and duripans influence water movement through regolith (Torrent et al., 1980; Ollier, 1991), and ultimately affect landscape evolution (Selby, 1982; Ollier, 1991).

On the California coast, duripans have been described in soils on marine terraces in San Diego and Orange

L.E. Moody, Soil Science Dep., California Polytechnic State Univ., San Luis Obispo, CA 93407; and R.C. Graham, Dep. of Soil and Environmental Sciences, Univ. of California, Riverside, CA 925210424. Contribution of the Dep. of Soil and Environmental Sciences, Univ. of California, Riverside. Received 21 Jan. 1997. *Corresponding author(lmoody@calpoly.edu).

Published in Soil Sci. Soc. Am. J. 61:1723-1729 (1997). counties (Torrent et al., 1980), and in soils formed in late to mid-Pleistocene coastal sand dunes in Santa Barbara County (D.L. Johnson et al., 1988, unpublished data). Both of these sites have a semiarid climate. Otherwise, most studies of marine terrace soils on the Pacific Coast of North America do not mention silica cementation (e.g., Orme, 1973; Muhs, 1982; Merritts et al., 1991; Bockheim et al., 1992), but silica cementation was observed in soils at south-facing edges of a dissected marine terrace on the California coast (Moody and Graham, 1995). In this study, our objectives were to: (i) determine the nature and extent of silica cementation in the marine terrace soils, and (ii) measure its effect on soil properties.

\section{MATERIALS AND METHODS}

\section{Study Area}

The study was conducted on a marine terrace approximately $4 \mathrm{~km}$ south of Los Osos, CA, about midway between Los Angeles and San Francisco (Fig. 1). The terrace is the third oldest in a sequence of four, first mapped in detail by Cleveland (1978). In the Los Osos area, marine terraces typically consist of wave-eroded bedrock platforms in siliceous shale, unconformably overlain by strata of littoral sandy and gravelly sediment, in turn overlain by interbedded beach and eolian sands (Moody and Graham, 1995). The age of the bedrock platform of this terrace was estimated at either 420000 or $480000 \mathrm{yr}$ by Moody and Graham (1995), and at $480000 \mathrm{yr}$ in a seismic study by the Pacific Gas and Electric Company (1988). Overlying sediments are younger than the bedrock platform but of undetermined age (Moody and Graham, 1995).

Two major drainageways bracket the study area: Islay Creek to the south and Hazard Canyon to the north. Islay Creek flows from east to west, and is a deeply incised perennial stream, dissecting the terraces into the bedrock. Hazard Canyon has an east-west trend at upper elevations and a northsouth trend at lower elevations. Hazard Canyon is occupied by an intermittent stream in the wet season. Several minor, unnamed drainageways dissect the terrace in the area between Islay Creek and Hazard Canyon.

South-facing edges of the terrace remnants typically have crescent-shaped scars (Fig. 2), some associated with Quaternary landslide deposits (Hall, 1973). Continuously cemented soil makes up about $20 \%$ of the south-facing edges. Where present, the cemented soil gives a square-shouldered shape to the scarps. The slopes below the scarps are littered with blocks of cemented soil material, from a few centimeters to $\approx 1 \mathrm{~m}$ in diameter. Thus, terrace dissection is proceeding by large- and small-scale mass wasting, as well as by runoff and stream downcutting.

Average annual precipitation is $460 \mathrm{~mm} \mathrm{yr}^{-1}$, most of which occurs in November through April. Average annual temperature is $15^{\circ} \mathrm{C}$ (Ernstrom, 1984). Vegetation consists of southern coastal scrub species, including California sagebrush (Artemesia californica Less.), coyote bush (Baccharis pilularis DC),

Abbreviations: $\mathrm{Fe}_{\omega}, \mathrm{Al}_{\circ}$, and $\mathrm{Si}_{0}$, oxalate-extractable $\mathrm{Fe}, \mathrm{Al}$, and $\mathrm{Si}$; $\mathrm{Fe}_{\mathrm{d}}$ and $\mathrm{Al}_{\mathrm{d}}$, dithionite-extractable $\mathrm{Fe}$ and $\mathrm{Al}: \mathrm{Si}_{\mathrm{T}}$, Tiron-extractable $\mathrm{Si} ; K_{\text {sal }}$ saturated hydraulic conductivity. 


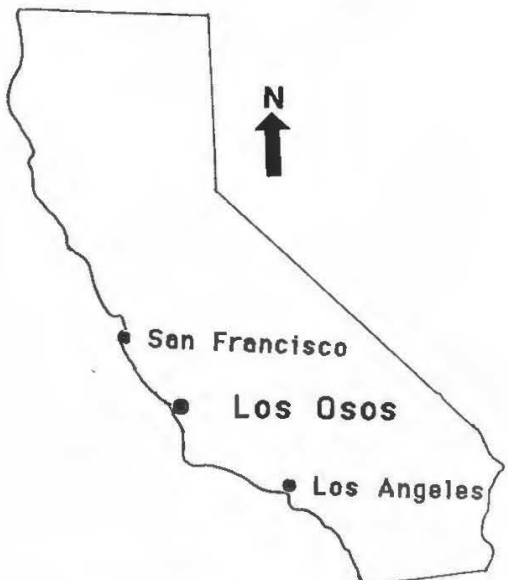

Fig. 1. Map of California, showing location of study area.

black sage (Salvia mellifera E. Greene), bush monkeyflower (Mimulus aurantiacus Curtis), Morro manzanita (Arcostaphylos morroensis Weisl. \& B. Schreiber), and poison oak (Toxicodendron diversilobum Torrey and A. Gray); grasses, including veldt grass (Ehrharta calycina Smith); and forbs. Vegetative cover is about $90 \%$ at the terrace interior. Vegetative cover at the cemented edge ranges from about 10 to $90 \%$, and is mostly shrubs.

\section{Field Methods}

The interior and edge pedons described here represent contrasting soils under a single geomorphic surface. Investigations of this terrace, as part of a larger geomorphic and stratigraphic sequence (Moody and Graham, 1995), revealed strongly contrasting soil morphological features between terrace interior locations and edges. Ten auger borings, equally spaced in a transect across the surface of two terrace remnants, and several small soil pits were used to identify a representative pedon at the terrace interior. Total transect length was $400 \mathrm{~m}$. This pedon, a coarse-loamy, mixed, thermic Typic Epiaquoll, was described and sampled in a hand-excavated pit according to standard methods (Soil Conservation Service, 1984; Soil Survey Division Staff, 1993), and classified using Soil Survey Staff (1994).

The edge exposure was chosen as representative after exam- ining outcrops exposed at the edges of the terrace. The edge exposure chosen faces south, toward Islay Creek (Fig. 2). The soil at the terrace edge was described after excavating 0.25 to $0.5 \mathrm{~m}$ into the cut bank to expose fresh soil material. Augering was used to investigate soils near the terrace edge and to determine the inward extent of morphological features. Water samples were collected from ephemeral springs at terrace toe (seaward edge) and edge positions for chemical analysis.

Saturated hydraulic conductivity was measured in the field with a compact constant-head permeameter (Amoozegar, 1989). The radius of the borehole was $3 \mathrm{~cm}$, and a constant head of 15 to $20 \mathrm{~cm}$ was maintained. Three to five measurements were made within each horizon of interest. The Glover equation was used to calculate saturated hydraulic conductivity $\left(K_{\text {sat }}\right)$ (Amoozegar, 1989). Scheffe's method of analysis of variance was used to compare $K_{\text {sat }}$ data between horizons (Steel and Torrie, 1980).

Penetration resistance of soils at and near the terrace edge was measured in the field with a Proctor penetrometer (Davidson, 1965) to quantitatively assess the degree of cementation. The axis of insertion was vertical. Moisture content was determined gravimetrically, and matric potential was determined by the filter paper method (Campbell and Gee, 1986).

\section{Laboratory Analyses}

Particle-size analysis followed removal of organic matter by $\mathrm{H}_{2} \mathrm{O}_{2}$ digestion, chemical dispersion using $10 \%$ sodium hexametaphosphate, and physical dispersion by mixing for $5 \mathrm{~min}$ in a blender. Sand, silt, and clay were determined by sieving and pipette (Gee and Bauder, 1986).

Selective dissolution techniques were sodium pyrophosphate (Bascomb, 1968), acid ammonium oxalate in the dark (Jackson et al., 1986), sodium citrate-bicarbonate-dithionite (Jackson et al., 1986), and Tiron (Kodama and Ross, 1991) to extract $\mathrm{Fe}, \mathrm{Al}$, and $\mathrm{Si}$ from gently ground, whole soil samples. Sodium pyrophosphate extraction was used to approximate organically chelated $\mathrm{Fe}$ and $\mathrm{Al}\left(\mathrm{Fe}_{\mathrm{p}}\right.$ and $\left.\mathrm{Al}_{\mathrm{p}}\right)$. Values of $\mathrm{Fe}_{\mathrm{p}}$ and $\mathrm{Al}_{\mathrm{p}}$ were subtracted from oxalate-extractable $\mathrm{Fe}_{\mathrm{o}}$ and $\mathrm{Al}_{\mathrm{o}}$ to approximate $\mathrm{Fe}$ in ferrihydrite and $\mathrm{Al}$ in noncrystalline aluminosilicates, having made the determination that the soils contain no detectable magnetite (Walker, 1983). Oxalateextractable $\mathrm{Si}\left(\mathrm{Si}_{0}\right)$ estimated $\mathrm{Si}$ in noncrystalline alumino Silicates (Jackson et al., 1986). Oxalate-extractable Fe and Al were subtracted from citrate-bicarbonate-dithionite-extract-

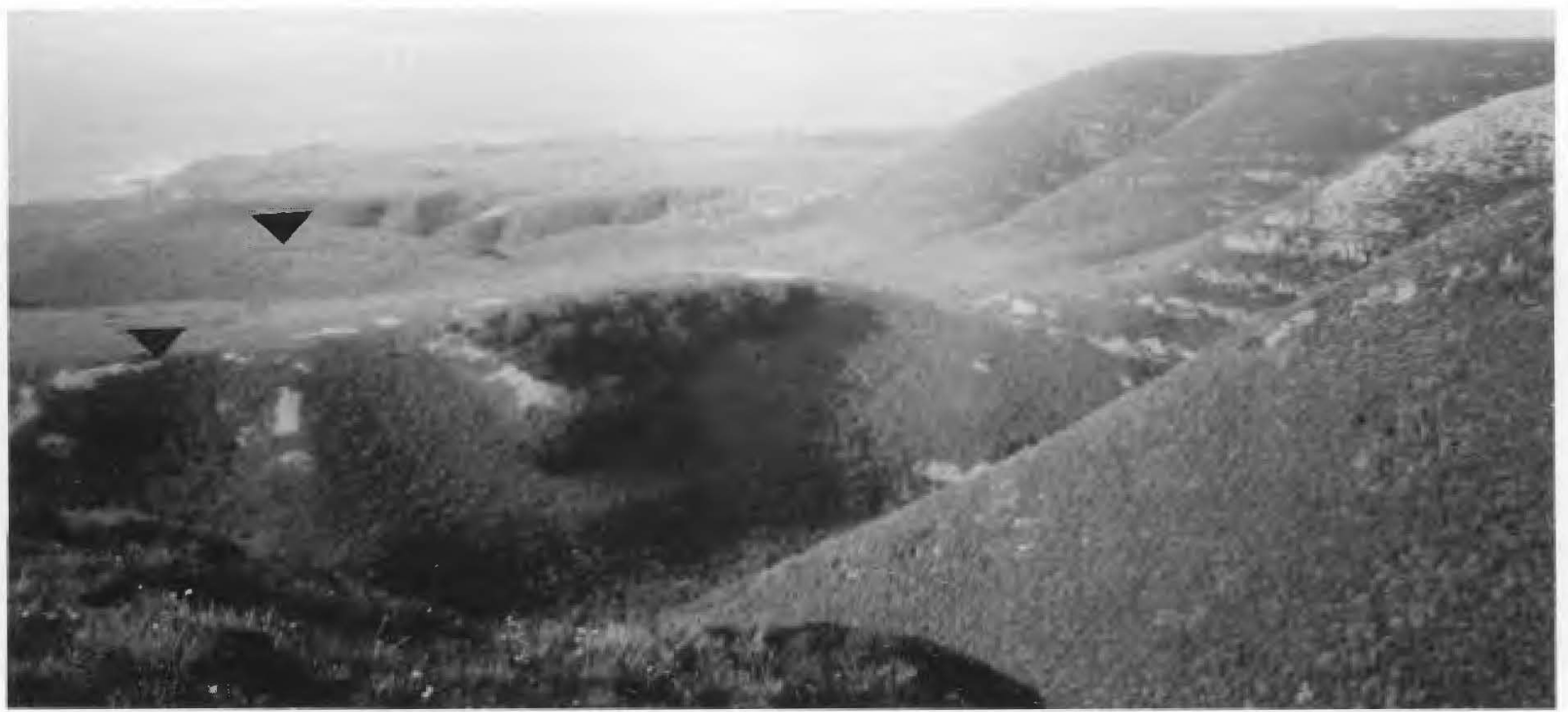

Fig. 2. Marine terrace landscape. Pedon locations are indicated by arrows. View is to the northwest. Deeply incised valley in foreground is the course of Islay Creek. 
able $\mathrm{Fe}_{\mathrm{d}}$ and $\mathrm{Al}_{\mathrm{d}}$ to estimate crystalline Fe oxides (Jackson et al., 1986). Values of $\mathrm{Si}_{i}$, were subtracted from Tiron-extractable $\mathrm{Si}_{\mathrm{r}}$ to estimate opaline silica (Kodama and Ross, 1991). Iron, $\mathrm{Al}$, and $\mathrm{Si}$ were measured by atomic absorption spectrophotometry and were calculated on a dry-weight basis. Water samples wcre analyzed for Si by inductively coupled plasma spectroscopy after filtration through $45-\mu \mathrm{m}$ filters.

Micromorphology of selected pedogenic features was described in thin sections of undisturbed samples, using polarized light microscopy. Descriptive terminology follows Brewer (1976)

\section{RESULTS AND DISCUSSION Soil Morphology, Micromorphology, and Selective Dissolution}

Both soils in this study have plinthite, consisting of closely spaced, strongly cemented nodules in a noncemented matrix (Btv horizons, Table 1). Nodules at the interior contain high levels of all forms of extractable $\mathrm{Fe}$, especially ferrihydrite and crystalline Fe oxides, and high levels of $\mathrm{Al}_{\diamond}$ and $\mathrm{Si}_{\circ}$ compared with the matrix (Table 2). Thus, the nodules appear to be cemented predominantly by Fe oxides with some allophanic material. The Btv horizon is continuous throughout the terrace, and allows correlation of horizons at the terrace interior with those at the edge. The Btv is exposed at the south-facing landslide scar but is covered by colluvium at the west- and north-facing edges.

Otherwise, soil morphology at the terrace interior is strikingly different from that at the terrace edge. The interior pedon consists of Ac horizons to $55-\mathrm{cm}$ depth, underlain by a Bwc horizon, all of which have sandy loam textures (Table 1). The Ac and Bwc horizons contain up to $25 \%$ (by weight) ironstone nodules. There is a slight clay bulge above the Btv1, although not taxonomically recognizable (Soil Survey Staff, 1994). Ferriargillans coat and bridge sand grains in the Bwc horizon. and indicate that some illuviation of clay has occurred (Table 1). The Btv horizons extend from immediately below the Bwc to the $155-\mathrm{cm}$ depth. Examination of thin sections of the nodules reveals that they contain more clay, organized into ferriargillans with strong continuous orientation, filling interstitial voids, than the matrix, but particle-size analysis was not performed on these nodules due to their cementation.

Below the Btv2 horizon, the soil (loamy fine sand texture) contains numerous, 1 -cm-diameter round mottles, to the $182-\mathrm{cm}$ depth. These mottles resemble the nodules in shape and size, but are soft to slightly hard, in contrast to the very to extremely hard nodules. This

Table 1. Selected morphological features of interior and edge pedons.

\begin{tabular}{|c|c|c|c|c|c|c|c|c|c|}
\hline Horizon & Depth & Moist color & Sand & Silt & Clay & $\begin{array}{c}\text { USDA } \\
\text { textural } \\
\text { classt }\end{array}$ & Structure $\doteqdot$ & Clay films & $\begin{array}{c}\text { Redox } \\
\text { features }\end{array}$ \\
\hline & $\mathrm{cm}$ & & 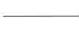 & & & & & & \\
\hline & \multicolumn{9}{|c|}{ Interior pedon (coarse-loamy, mixed, thermic Typic Epiaqnoll) } \\
\hline Ac1 & $0-29$ & $2.5 Y 3 / 2$ & 71.6 & 21.3 & 7.1 & sl & Ifsbk & 0 & Fe concretions \\
\hline Ac2 & $29-40$ & 2.5 Y $3 / 2$ & 71.4 & 19.0 & 9.6 & sl & 1fshk & 0 & Fe concretions \\
\hline Ac3 & $40-55$ & $2.5 \times 3 / 3$ & 70.2 & 22.7 & 7.1 & sl & $1 \mathrm{msbk}$ & 0 & Fe concretions \\
\hline & & & & & & & & Coating and bridging & \\
\hline $\begin{array}{l}\text { Bwe } \\
\text { Btv1 }\end{array}$ & $\begin{array}{l}55-90 \\
90-132\end{array}$ & 2.5 Y $5 / 2$ & 74.6 & 23.0 & 5.3 & sl & $\begin{array}{l}\text { ma } \\
\text { ms }\end{array}$ & sand grains & $\begin{array}{l}\text { Fe concretions } \\
\text { Fe nodules }\end{array}$ \\
\hline matrix & & 2.5 Y $5 / 2$ & 74.6 & 18.9 & 6.4 & sl & & Lining pores & \\
\hline nodules & & 10YR $5 / 6$ & nd\$ & nd & nd & nd & & Lining pores & \\
\hline Btv2 & $132-155$ & & & & & & ms & & Fe nodules \\
\hline matrix & & 10YR $5 / 3$ & 76.0 & 16.8 & 7.2 & sl & & Lining pores & \\
\hline $\begin{array}{l}\text { nodules } \\
\text { Bt1 }\end{array}$ & $155-182$ & $10 Y R 5 / 6$ & nd & nd & nd & nd & ms & Lining pores & Fe concentrations \\
\hline matrix & & $10 \mathrm{YR} 5 / 6$ & 81.0 & 14.6 & 4.4 & Ifs & & Lining pores & \\
\hline concentrations & & $10 Y R 4 / 6$ & nd & nd & nd & nd & & Lining pores & \\
\hline B12 & $182-235$ & $10 \mathrm{YR} 5 / 6$ & 81.0 & 12.5 & 6.4 & Ifs & ma & Lining pores & 0 \\
\hline \multirow[t]{2}{*}{ Bt3 } & $235-271$ & 10 YR $5 / 6$ & 81.8 & 10.3 & 7.9 & Ifs & nd & nd & 0 \\
\hline & \multicolumn{9}{|c|}{ Edge pedon } \\
\hline Ac & 0-30 & $2.5 Y 3 / 2$ & $\mathbf{7 2 . 0}$ & 20.0 & 8.0 & sI & Ifsbk & 0 & Fe concretions \\
\hline Btqm & $30-46$ & 10YR $3 / 2$ & 72.4 & 18.2 & 9.4 & sl & $\begin{array}{l}\text { lmpl, npper } \\
3 \text { cm, over } \\
\text { l coabk }\end{array}$ & Between peds & Fe concretions \\
\hline Btv & $46-89$ & & & & & & lcosbk & & Fe nodules \\
\hline matrix & & $2.5 Y 4 / 0$ & 67.7 & 16.3 & 16.0 & sl & & Lining pores & \\
\hline concentrations & & 10YR 4/6 & nd & nd & nd & nd & & Lining pores & \\
\hline Bt/Btg1 & $89-190$ & & & & & & $2 \operatorname{cosbk}$ & & Fe depletions \\
\hline matrix & & $10 Y R 4 / 6$ & 72.3 & 8.2 & 19.6 & sI & & Lining pores & \\
\hline seams & & $10 \mathrm{YR} 5 / 1$ & 67.8 & 10.4 & 21.9 & scl & & Between peds & \\
\hline Bt/Btg2 & $190-223$ & & & & & & 3 copr & & Fe depletions \\
\hline matrix & & $10 \mathrm{YR} 4 / 6$ & 78.1 & 5.9 & 16.0 & sl & & Lining pores & \\
\hline seams & & $10 Y R 6 / 1$ & 76.9 & 5.9 & 17.3 & sl & & Between peds & \\
\hline Bt/Btg3 & $223-300$ & & & & & & 3 copr & & Fe depletions \\
\hline matrix & & $2.5 Y 4 / 4$ & 82.5 & 1.3 & 16.1 & sl & & Lining pores & \\
\hline seams & & 10YR $6 / 1$ & nd & nd & nd & nd & & Between peds & \\
\hline Bt/Btg4 & $300-360$ & & & & & & 3 copr & & Fe depletions \\
\hline matrix & & $10 \mathrm{YR} 5 / 4$ & 81.2 & 2.1 & 16.7 & sl & & Lining pores & \\
\hline seams & & 10YR $6 / 1$ & 72.5 & 0.7 & 26.8 & scl & & Between peds & \\
\hline
\end{tabular}

$\dagger$ sl, sandy loam; Ifs, loamy fine sand; scl, sandy clay loam.

† 1 ssbk, weak fine subangular blocky; 1 msbk, weak medium subangular blocky; ma, massive; 1 mpl, weak medium platy; 1 coabk, weak coarse angular blocky; 1cosbk, weak coarse subangular blocky; 2cosbk, moderate coarse subangular blocky; 3copr, strong coarse prismatic.

$\$$ nd, not determined. 
Table 2. Selective dissolution data for interior and edge pedons.

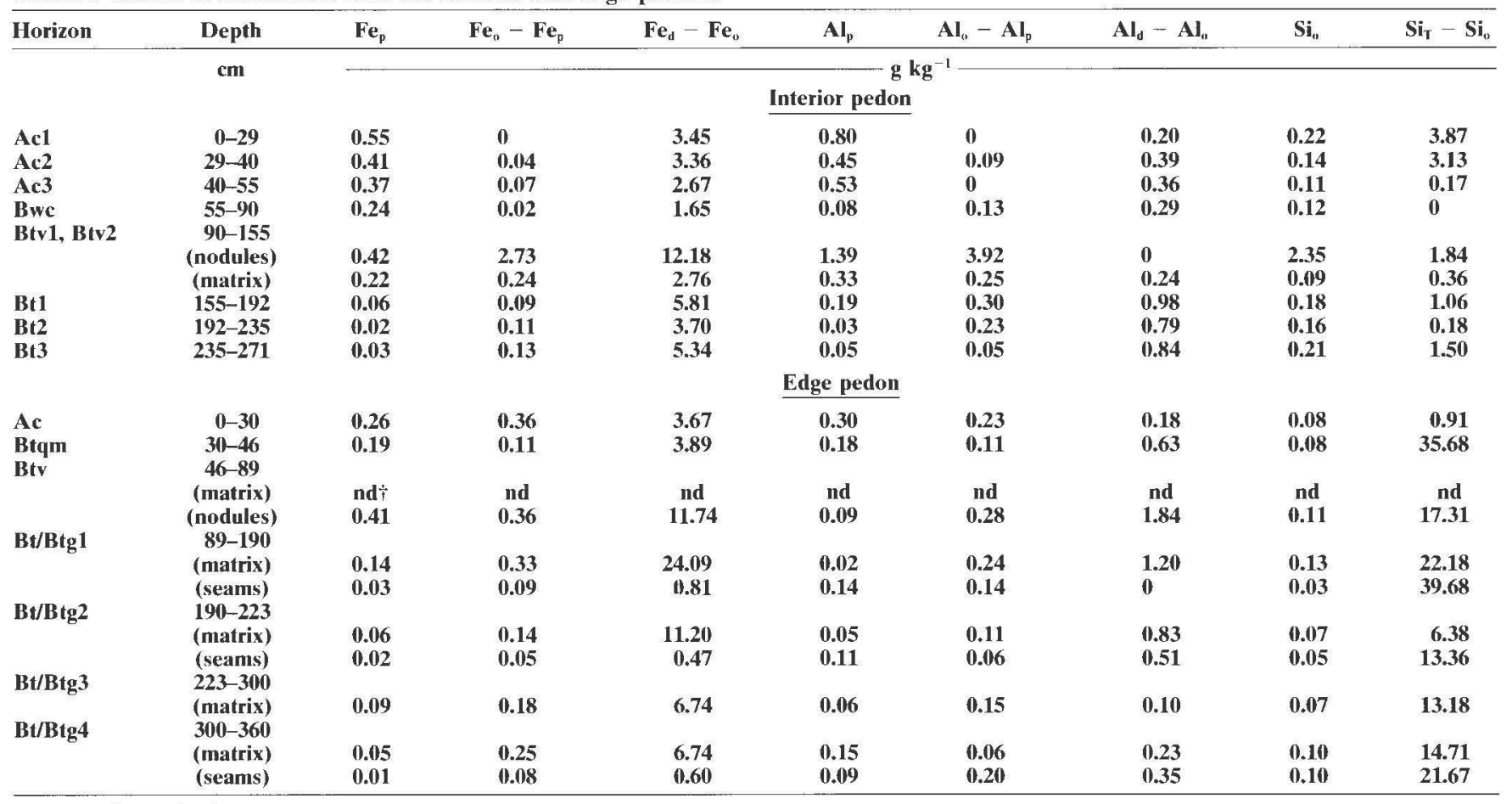

ind, not determined.

horizon is underlain by uniformly yellowish brown (10YR 5/6, moist) loamy fine sand, with thin ferriargillans lining interstitial voids, to $>270$ - $\mathrm{cm}$ depth (Table 1). Ferriargillans line, and sometimes fill, simple packing voids in these horizons. This evidence of illuviation of clays and $\mathrm{Fe}$ oxides prompted us to name these Bt horizons in spite of a lack of clay increase relative to overlying horizons (Table 1).

The contrasting terrace edge pedon consists of $30 \mathrm{~cm}$ of Ac horizon with sandy loam texture. The Ac horizon is underlain by a Btqm horizon to the 46- $\mathrm{cm}$ depth (Table 1). The Btqm has been exposed to the surface by erosion of the overlying A horizon along part of the edge. Clods from the Btqm horizon did not slake after soaking in water or $1 \mathrm{M} \mathrm{HCl}$ for $>24 \mathrm{~h}$. The horizon has thick (up to $1 \mathrm{~cm}$ ) argillans, poorly oriented in thin section. Silica in this horizon takes two forms: thick (up to $0.5 \mathrm{~cm}$ ) white to light gray (10YR $8 / 1$ to $10 \mathrm{YR} 7 / 2$, moist) silans filling root channels and fractures, and often associated with argillans; and gray (10YR 3/2, moist) silans, filling simple packing voids. In thin section, these interstitial silans have high relief in plane polarized light, and are isotropic under crossed polarizers (Fig. 3 ). The channel and fracture silans are also isotropic under crossed polarizers. These optical properties, plus selective dissolution data, suggest the cement is opal.

Below the $89-\mathrm{cm}$ depth, several $\mathrm{Bt} / \mathrm{Btg}$ horizons have a yellowish brown ( $10 \mathrm{YR} 4 / 6$ or $5 / 4$, or $2.5 \mathrm{YR} 4 / 4$, moist) matrix $(\mathrm{Bt})$, with common, prominent, vertical gray (10YR 5/1 to 6/1, moist) seams (Btg), about 15 to 25 $\mathrm{cm}$ apart (Table 1). The gray seams occur as haloes at ped faces, outlining polygonal prisms in plan view. Their color suggests they are Fe depleted compared with the matrix. Selective dissolution data confirm this, in that both $\mathrm{Fe}_{\mathrm{o}}$ and $\mathrm{Fe}_{\mathrm{d}}$ values are at least an order of magnitude less in the seams than in the matrix (Table 2). Though Fe depleted, the gray seams are not clay depleted. Simple packing voids within the seams are nearly filled with argillans, and soil material from the seams contains at least as much clay as the matrix (Table 1). Furthermore, the cracks between the prisms are partially filled with thick (up to $1 \mathrm{~cm}$ ) argillans. Overall, horizons below the Btv at the terrace edge have more clay than horizons from equivalent depths of the terrace interior (Table 1).

Values of $\mathrm{Fe}_{\mathrm{d}}$ in horizons above the Btv horizon are within the same order of magnitude in both interior and edge pedons (Table 2). Below the Btv horizon, $\mathrm{Fe}_{\mathrm{d}}$ values are slightly to substantially higher in the matrices of the $\mathrm{Bt} / \mathrm{Btg}$ horizons at the edge than at the interior. Since clay contents of these horizons are also higher at the edge than the interior (Table 1), Fe oxides may have been concentrated at the edge along with clays, possibly by lateral illuviation in response to edgeward subsurface flow as terrace dissection proceeded (Moody and Graham, 1994, 1995). Values of $\mathrm{Al}_{0}$ and $\mathrm{Al}_{\mathrm{d}}$ were about the same in the interior and edge profiles (Table 2).

Opal contents $\left(\mathrm{Si}_{\mathrm{T}}-\mathrm{Si}_{\mathrm{o}}\right)$ are higher throughout most of the edge pedon than in the interior pedon, especially in the gray seams (Table 2). Petrographic examination showed that, in the gray seams, simple packing voids are nearly to completely filled with well-oriented clay material. The opal cannot be seen in thin section and is apparently dispersed within the clay material.

\section{Silica Cementation}

As discussed above, microscopic examination of thin sections and $\mathrm{Si}_{\mathrm{T}}-\mathrm{Si}_{0}$ data showed the cementing mate- 

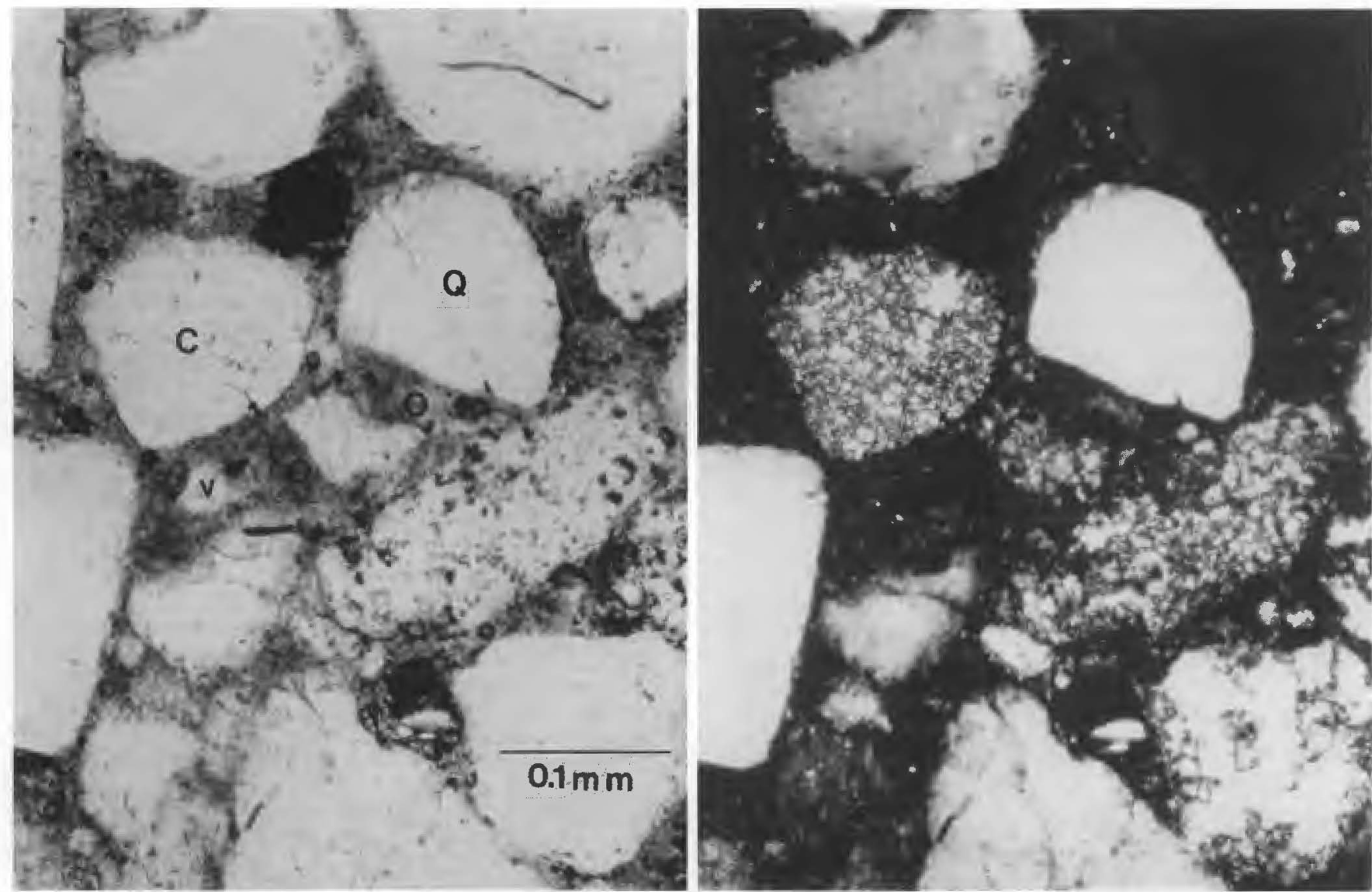

Fig. 3. Photomicrographs of silica-cemented Btqm horizon, edge pedon, showing opaline silica cement (O), void (v), and sand grains consisting of quartz (Q) and chert $(C)$. Views are in plane polarized light on left, crossed polarizers on right.

rial in the Btqm horizon at the terrace edge to be opaline silica. The opal contains entrained silt-sized and smaller particles and fills simple packing voids in the s-matrix. It has no discernible orientation in microscopic view, in contrast with most duripans (Torrent et al., 1980; Chadwick et al., 1987; Boettinger and Southard, 1990). The silica-cemented Btqm horizon lacks a clear laminar cap, and exhibits only weak and discontinuous platy structure over angular blocky fragments separated by fractures (Table 1). In addition, the cemented soil material lacks reniform surfaces associated with at least some silcretes (Ollier, 1991). For these reasons, the silicacemented Btqm horizon is not, and should not be identified as, a duripan.

The silica-cement zone extends back into the terrace to about $4 \mathrm{~m}$ from the edge. Penetration resistance, used as a relative measure of cementation, is by far highest at the edge, and declines sharply inward (Table 3). Petrographic examination of thin sections showed that correspondingly less of the interstitial pore space is filled with opaline cement, from the terrace edge inward. In weakly cemented soil material, the opal coats and bridges sand grains. In moderately cemented material, the opal partially fills packing voids, and is especially thick in pore throats at sand grain contacts (Fig. 3). In strongly cemented soil material, packing voids are filled with opal. Opaline Si declines and allophanic Si increases slightly inward from the edge (Table 3 ).

Water collected from ephemeral springs at terrace edge positions in the study area contained 7.8 to 19.1

Table 3. Extractable Si, penetration resistance, and moisture content and potential within the silica-cemented horizon in a transect from the terrace edge toward the interior.

\begin{tabular}{|c|c|c|c|c|c|c|}
\hline $\begin{array}{l}\text { Distance } \\
\text { from silica- } \\
\text { cemented } \\
\text { edge }\end{array}$ & Horizon & $\begin{array}{c}\text { Sampling } \\
\text { depth }\end{array}$ & $\mathbf{S i}_{0}$ & $\mathbf{S i}_{\mathbf{T}}-\mathbf{S i}_{\mathbf{0}}$ & $\begin{array}{c}\text { Penetration } \\
\text { resistance }\end{array}$ & $\underset{\text { potential } \dagger}{\text { Matric }}$ \\
\hline m & & $\mathrm{cm}$ & \multicolumn{2}{|c|}{$\longrightarrow \mathrm{g} \mathrm{kg}^{-1}$} & $\mathrm{~kg} \mathrm{~cm}^{-2}$ & $\mathrm{~J} \mathrm{~kg}^{-1}$ \\
\hline 0 & Btgm & $0-9$ & 0.08 & 35.68 & $>1223$ & -2700 \\
\hline 3.3 & Btqm & 25-35 & ndt & nd & 792 & -2200 \\
\hline 4.9 & Btq & $45-55$ & 0.22 & 27.39 & 171 & -2000 \\
\hline 6.4 & Btq & $65-75$ & 0.27 & 12.85 & 86 & -2300 \\
\hline 8.4 & Btq & $70-75$ & 0.43 & 9.80 & 145 & -2000 \\
\hline 10.4 & Bwc & $75-80$ & 0.52 & 6.39 & 122 & -2000 \\
\hline
\end{tabular}

† Values at time of sampling for penetration resistance.

¥ nd, not determined. 
$\mathrm{mg} \mathrm{L}^{-1} \mathrm{Si}$. These waters are not supersaturated with $\mathrm{Si}$, but upon drying at the terrace edge, the activity of $\mathrm{Si}$ in solution as $\mathrm{Si}(\mathrm{OH})_{4}$ increases sufficiently for $\mathrm{Si}(\mathrm{OH})_{4}$ polymerization. Further drying and dehydration of the polymers results in formation of opal (Chadwick et al., 1987).

Somewhat analogous silica cementation has been described in sandstones by Thiry et al. (1988). Silicacemented lenses in the sandstones have resulted from lateral groundwater flow and discharge in a dissected landscape. These researchers suggest that each lens represents a fossil groundwater discharge site at the bank of an incised channel. Successively lower silica lenses reflect a drop in water table with deepening incision of the landscape. Groundwater from this aquifer contains 10 to $18 \mathrm{mg} \mathrm{L}^{-1} \mathrm{Si}$, similar to the $\mathrm{Si}$ content of the ephemeral springs sampled in this study.

\section{Hydraulic Conductivity}

At the terrace interior, $K_{\text {sat }}$ is significantly lower in the Btv horizon than in the Bwc horizon $(P=0.05$; Table 4). The Btv horizon, slowly permeable to water, is thus verified to be restrictive, though not impervious, to downward infiltration. Ordinarily, in sandy soils, $\mathrm{Si}$ may be expected to leach out of surface horizons into deep horizons or entirely out of the profile. However, at the terrace interior described here, the Btv horizon forms a pan that effectively prevents downward leaching. Throughflow carries Si-bearing waters to exfiltration sites, and drying at the terrace edge enables the $\mathrm{Si}$ to precipitate in the soil.

The $K_{\text {sat }}$ of the $\mathrm{Bt} / \mathrm{Btg} 1$ matrix at the terrace edge was substantially lower than that of the Fe-depleted seams separating prisms within the same horizon. Observation of springs at the terrace edge revealed that water exfiltrates preferentially from macropores within the gray seams. Vepraskas (1992) has shown that saturated and reducing conditions in soil contiguous to macropores contributes to the formation of Fe-depleted, gray mottles.

The $K_{\text {sat }}$ in the Btqm horizon at the terrace edge is significantly lower $(P=0.05)$ than in the Bwc horizon $>10 \mathrm{~m}$ from the edge (Table 4). These data show that water movement through soil at the terrace edge is restricted as silica cement fills pore space.

Table 4. Saturated hydraulic conductivity $\left(K_{\text {sat }}\right)$ values for selected horizons at terrace interior and edge.

\begin{tabular}{lcc}
\hline Depth & Horizon & \multicolumn{1}{c}{$K_{\text {sat }}$} \\
\hline $\mathrm{cm}$ & Terrace interior & $\mathrm{cm} \mathrm{h}^{-1}$ \\
& Bwc $(n \dagger=3)$ & \\
85 & Terrace edge & $7.7 \mathrm{a} \neq$ \\
100 & Btv1 $(n=3)$ & $0.5 \mathrm{~b}$ \\
& Btm $(n=4)$ & \\
35 & Bt/Btg1, matrix $(n=3)$ & $0.1 \mathrm{~b}$ \\
120 & $(n=2) \&$ & $0.1 \mathrm{~b}$ \\
120 & gray Fe-depleted seams & 3.1 \\
\hline
\end{tabular}

$\dagger n$, sample size.

\# Numbers followed by the same letter are not significantly different at $P=0.05$.

§ Significance not tested because of small sample size.

\section{Redoximorphic Processes}

Daniels and Gamble (1967) found a range of morphological properties, which they called edge effect, at the dissected edge of a Coastal Plain surface. Redoximorphic depletions and concentrations were less prevalent where edge conditions were dry than at "wet edges" adjacent to depressions where water accumulated. In this study, redoximorphic depletions below the Btv horizon are more intense at the edge than at the terrace interior. The deep part of the edge pedon is analogous to the wet edge of Daniels and Gamble (1967), in contrast to the upper part of the profile, in which dry conditions allow opaline silica cementation.

The marine terrace described here has evolved to a stage in which stream incision is deep and the terrace is highly dissected. Because of the seaward slope of the bedrock platform of the terrace, the change in flow patterns induced by dissection, and the water potential gradient induced by evaporation of water from the terrace edge, subsurface water moves toward the terrace edge by both saturated and unsaturated flow. Near the terrace edge, cracks form as the soil dries and shrinks during dry summer months. These cracks become preferential flow paths within a soil matrix otherwise plugged with illuvial clay. Because the soil material bounding the cracks is seasonally saturated, reduction and solubilization of $\mathrm{Fe}$ has occurred.

\section{Implications for Landscape Evolution}

Early in emergent terrace history, water moves freely through the sandy soil s-matrix in a seaward direction (Moody and Graham, 1994). Dissection of terrace sediments by streams and gullies alters the direction of water movement within the regolith, while pore spaces are progressively filled with clay-sized material (Moody and Graham, 1995). At the stage of terrace evolution considered in this study, soil morphological features affect the paths and direction of throughflow, and also affect landscape evolution. Opaline silica has cemented the soil at the terrace edge. Unlike the noncemented soil above and below it, silica-cemented soil resists erosion by particle detachment and transport in runoff. Mass wasting by blockfall of silica-cemented soil has become an important process in terrace dissection. Scarp retreat at the terrace edge may occur as alternating episodes of cementation and blockfall. During periods of saturation above the plinthite, effective cohesion between cemented blocks declines as macropores fill with water. Thus, shear strength between blocks is nil, and blockfall occurs due to gravity force on the blocks. Although the silica-cemented edge is not a dominant feature in terms of areal extent on this terrace remnant, it has a substantial effect on the morphology of the scarp.

Soil exposures at dissected edges of many landforms are commonly used for soil descriptions in pedologic and geologic research, teaching, and resource assessment. The results of this study suggest caution should be used with this approach. The use of edge exposures in soil studies must be preceded by understanding how land dissection affects water movement and the interre- 
lationships of soil morphology, hydrology, and geomorphology. Edge exposures may not be typical of the soils under a geomorphic surface, though they may give valuable insight about geomorphic and pedogenic processes.

\section{ACKNOWLEDGMENTS}

We thank Paul Mosher, April Ulery, Jim Moody, and Audrey Senelly for help with field work, Cara Vidano, Hiram Garcia, and Steven Cole for ICP analyses, and the staff of Montana de Oro State Park.

\section{REFERENCES}

Amoozegar, A. 1989. A compact constant-head permeameter for measuring saturated hydraulic conductivity of the vadose zone. Soil Sci. Soc. Am. J. 53:1356-1361.

Bascomb, C.L. 1968. Distribution of pyrophosphate-extractable iron and organic carbon in soils of various groups. J. Soil Sci, 19:251-268.

Bates, R.L., and J.A. Jackson (ed.). 1984. Dictionary of geological terms. 3rd ed. Doubleday, New York.

Blank, R.R., and M.A. Fosberg. 1991. Duripans of Idaho, U.S.A.: In situ alteration of eolian dust (loess) to an opal-A/x-ray amorphous phase. Geoderma 48:131-149.

Bockheim, J.G., H.M. Kelsey, and J.G. Marshall III. 1992. Soil development, relative dating, and correlation of late Quaternary marine terraces in southwestern Oregon. Quat. Res. 37:60-74.

Boettinger, J.L., and R.J. Southard. 1990. Micromorphology and mineralogy of a calcareous duripan formed in granitic residuum, Mojave Desert, California, USA. In L.A. Douglas (ed.) Soil micromorphology. Elsevier, Amsterdam.

Brewer, R. 1976. Fabric and mineral analysis of soils. 2nd ed. John Wiley \& Sons, New York.

Campbell, G.S., and G.W. Gee. 1986. Water potential: Miscellaneous methods. p. 619-633. In A. Klute (ed.) Methods of soil analysis. Part 1. 2nd ed. Agron. Monogr. 9. ASA and SSSA, Madison, WI.

Chadwick, O.A., D.M. Hendricks, and W.D. Nettleton. 1987. Silica in duric soils: I. A depositional model. Soil Sci. Soc. Am. J. 51:975-982.

Cleveland, G.B. 1978. Geologic map of the Point Buchon area, San Luis Obispo County, California. Open File Rep. 78-17. Calif. Div. Mines and Geology, Sacramento.

Daniels, R.B., and E.E. Gamble. 1967. The edge effect in Ultisols in the North Carolina Coastal Plain. Geoderma 1:117-124.

Davidson, D.T. 1965. Penetrometer measurements. p. 471-484. In C.A. Black (ed.) Methods of soil analysis. Part 1. Agron. Monogr. 9. ASA, Madison, WI.

Ernstrom, D.J. 1984. Soil survey of San Luis Obispo County, California, coastal part. U.S. Gov. Print. Office, Washington, DC.

Flach, K.W., W.D. Nettleton, L.H. Gile, and J.G. Cady. 1969. Pedocementation: Induration by silica, carbonates, and sesquioxides in the Quatenary. Soil Sci. 107:442-453.

Gee, G.W., and J.W. Bauder. 1986. Particle-size analysis. p. 383-411.
In A. Klute (ed.) Methods of soil analysis. Part 1. 2nd ed. Agron. Monogr. 9. ASA and SSSA, Madison, WI.

Hall, C.A. 1973. Geologic map of the Morro Bay South and Port San Luis quadrangles, San Luis Obispo County, California. U.S. Geol Surv. Misc. Field Stud. MF 511.

Jackson, M.L., C.H. Lim, and L.W. Zelazny. 1986. Oxides, hydroxides, and aluminosilicates. p. 101-150. In A. Klute (ed.) Methods of soil analysis. Part 1. 2nd ed. Agron. Monogr. 9. ASA and SSSA, Madison, WI.

Kodama, H., and G.J. Ross. 1991. Tiron dissolution method used to remove and characterize inorganic components in soils. Soil Sci. Soc. Am. J. 55:1180-1187.

Merritts, D.J., O.A. Chadwick, and D.M. Hendricks. 1991. Rates and processes of soil evolution on uplifted marine terraces, northern California. Geoderma 51:241-275.

Moody, L.E., and R.C. Graham. 1994. Pedogenic processes in thick sand deposits on a marine terrace. p. 41-55. In D.L. Cremeens et al. (ed.) Whole regolith pedology. SSSA Spec. Publ. 34. SSSA, Madison, WI.

Moody, L.E., and R.C. Graham. 1995. Geomorphic and pedogenic evolution in coastal sediments, central California. Geoderma 67:181-201.

Muhs, D.R. 1982. A soil chronosequence on Quaternary marine terraces, San Clemente Island, California. Geoderma 28:257-283.

Ollier, C.D. 1991. Aspects of silcrete formation in Australia. S. Geomorphol. 35:151-163.

Orme, A.R. 1973. Quaternary deformation of western Baja California, Mexico, as indicated by marine terraces and associated deposits. Tech. Rep. 0-72-6. Office of Naval Research, Los Angeles, CA.

Pacific Gas and Electric Company. 1988. Final report of the Diablo Canyon long term seismic program for the Diablo Canyon Power Plant. P.G. and E. Co., San Francisco, CA.

Selby, M.J. 1982. Hillslope materials and processes. Oxford Univ. Press, Oxford, England.

Soil Conservation Service. 1984. Procedures for collecting soil samples and methods of analysis for soil survey. USDA-SCS Soil Surv. Invest. Rep. no. 1. U.S. Gov. Print. Office, Washington, DC.

Soil Survey Division Staff. 1993. Soil survey manual. Agric. Handb. 18. U.S. Gov. Print. Office, Washington, DC.

Soil Survey Staff. 1994. Keys to soil taxonomy. 6th ed. U.S. Gov. Print. Office, Washington, DC.

Steel, R.G.D., and J.H. Torrie. 1980. Principles and procedures of statistics. 2nd ed. McGraw-Hill, New York.

Thiry, M., M.B. Ayrault, and J.C. Grisoni. 1988. Ground-water silicification and leaching in sands: Example of the Fontainebleau Sand (Oligocene) in the Paris Basin. Geol. Soc. Am. Bull. 100:1283-1290.

Torrent, J., W.D. Nettleton, and G. Borst. 1980. Genesis of a Typic Durixeralf of southern California. Soil Sci. Soc. Am. J. 44:575-582.

Vepraskas, M.J. 1992. Redoximorphic features for identifying aquic conditions. Tech. Bull. 301. North Carolina Agric. Res. Serv., Raleigh.

Walker, A.L. 1983. The effects of magnetite on oxalate- and dithioniteextractable iron. Soil Sci. Soc. Am. J. 47:1022-1026. 